\title{
POTENSI LIGNIN UNTUK PENANGANAN LOGAM BERAT Cr(VI)
}

\section{(LIGNIN POTENTIALS TO REMOVAL OF Cr(VI))}

\author{
Yuris*, Chandrawati Cahyani, dan Atikah \\ Jurusan Kimia, Fakultas Kimia dan IImu Pengetahuan Alam, Universitas Brawijaya \\ *E-mail: yurisBIMA@gmail.com
}

Received :26 Januari 2014; revised :07 April 2014; accepted : 07 April 2014

\begin{abstract}
ABSTRAK
Lignin telah diisolasi dari lindi hitam dengan pengasaman menggunakan $\mathrm{H}_{2} \mathrm{SO}_{4} 10 \%$ pada pH 2 dan diperoleh lignin yang memiliki gugus fungsi mirip Indulin-AT. Lignin memiliki sifat tidak larut dalam air dan larut dalam basa. Logam berat $\mathrm{Cr}(\mathrm{VI})$ merupakan salah satu logam berat yang bersifat toksik tinggi dan sangat larut dalam air sehingga dapat terdistribusi kemana-mana. Tujuan penelitian ini adalah mengkaji potensi lignin untuk penanganan logam berat $\mathrm{Cr}(\mathrm{VI})$, kajian difokuskan pada variasi $\mathrm{pH}$ 2-10 dan konsentrasi lignin. Hasil penelitian menunjukkan bahwa pada $\mathrm{pH}$ campuran 2, penggunaan lignin sebesar $2000 \mathrm{ppm}$ sebanyak $25 \mathrm{~mL}$ mampu menyisihkan $\mathrm{Cr}(\mathrm{VI})$ sebesar 85,83\% dari konsentrasi awal $\mathrm{Cr}(\mathrm{VI}) 25 \mathrm{ppm}$ sebanyak $10 \mathrm{~mL}$ menjadi 1,012 ppm. Penambahan konsentrasi lignin pada $\mathrm{pH}<5$ menaikkan penyisihan $\mathrm{Cr}(\mathrm{VI})$ karena terjadi proses adsorbsi dan kopresipitasi melalui mekanisme oklusi sedangkan pada $\mathrm{pH}>5$, penambahan konsentrasi lignin hanya menaikkan penyisihan $\mathrm{Cr}(\mathrm{VI})$ relatif sedikit dibanding pada $\mathrm{pH}<5$ karena peristiwa kopresipitasi tidak terjadi seiring dengan mulai larutnya lignin.
\end{abstract}

Kata kunci: Lignin, Koprespitasi, Adsorpsi, Oklusi

\begin{abstract}
Lignin has been isolated from black liquor with acidification by using $\mathrm{H}_{2} \mathrm{SO}_{4} 10 \%$ on $\mathrm{pH}$ 2. The lignin obtained will have similarity to functional groups of Indulin-AT standard lignin. Lignin is insoluble in water but soluble in alkaline solvents. Chromium (VI) is one of toxic heavy metals, which is so insoluble in water that can be distributed everywhere. The purpose of this study is assess the potential of lignin to removal of $\mathrm{Cr}(\mathrm{VI})$, while the focus of the study is on $\mathrm{pH}$ variation and lignin concentration. The results showed that, in $\mathrm{pH}$ of mixture 2 , a $25 \mathrm{~mL}$ of 2000 ppm lignin was able to remove up to $85.83 \% \mathrm{Cr}(\mathrm{VI})$ from a $10 \mathrm{~mL} \mathrm{Cr}(\mathrm{VI})$ with initial concentration of $25 \mathrm{ppm}$ to $1.012 \mathrm{ppm}$. The addition of lignin concentration at $\mathrm{pH}<5$ increase the removal of $\mathrm{Cr}(\mathrm{VI})$ due to adsorption and co-precipitation process through occlusion mechanism, whereas at $\mathrm{PH}>5$, the addition of lignin concentration will raise $\mathrm{Cr}(\mathrm{VI})$ removal in relatively small scale, as co-precipitation did not occur in line with lignin dissolution.
\end{abstract}

Key word: Lignin, Coprecipitation, Adsorption, Occlusion

\section{PENDAHULUAN}

Sekitar $47 \%$ dari senyawa organik dalam lindi hitam adalah lignin (Lewis \& Lantzi dalam Hermingway et al., 1988). Salah satu industri yang menghasilkan limbah cair yang mengandung logam berat adalah industri elektroplating. Limbah cair perlu dikelola dan ditangani terlebih dahulu agar tidak mengganggu lingkungan dan kehidupan di sekitarnya. Salah satu logam berat yang berbahaya adalah krom, terutama yang bervalensi +6 yang sangat larut dalam air.

Agar pemanfaatan lignin dapat dilakukan secara optimal maka perlu diketahui dan dipahami secara mendalam melalui eksperimen tentang potensi lignin untuk penanganan logam berat $\mathrm{Cr}(\mathrm{VI})$ pada berbagai $\mathrm{pH}$ dan konsentrasi. Manfaat yang diharapkan dari penelitian ini adalah memberikan alternatif penanganan logam berat $\mathrm{Cr}(\mathrm{VI})$, dimana bahan yang digunakan merupakan bahan yang berasal dari limbah yang tidak diinginkan.

Air yang mengandung ion $\mathrm{Cr}(\mathrm{III})$ akan menimbulkan masalah karena dapat berubah menjadi $\mathrm{Cr}(\mathrm{VI})$ oleh proses oksidasi. Logam $\mathrm{Cr}(\mathrm{VI})$ bersifat toksik, dalam metabolisme tubuh akan menghalangi atau mampu menghambat 
kerja dari enzim benzopiren hidroksilase (enzim yang berfungsi menghambat pertumbuhan kanker yang disebabkan oleh asbestos). Penghalangan kerja enzim benzopiren hidroksilase dapat mengakibatkan perubahan kemampuan pertumbuhan sel, sehingga sel-sel menjadi tumbuh secara liar dan tidak terkontrol, atau lebih dikenal dengan istilah kanker (Palar, 1994). Bergantung pada $\mathrm{pH}, \mathrm{Cr}$ di atas $\mathrm{pH} 6$ berada sebagai spesi $\mathrm{CrO}_{4}{ }^{2-}$ sedangkan pada rentang $\mathrm{pH} 1$ hingga $\mathrm{pH} 6, \mathrm{HCrO}_{4}{ }^{-}$dan $\mathrm{Cr}_{2} \mathrm{O}_{7}{ }^{2-}$ berada pada kesetimbangan. Pada $\mathrm{pH}$ di bawah 1 spesies yang utama adalah $\mathrm{H}_{2} \mathrm{CrO}_{4}$. Penambahan asam menyebabkan kesetimbangan bergeser kearah $\mathrm{Cr}_{2} \mathrm{O}_{7}{ }^{2-}$ dan penambahan basa menyebabkan kesetimbagan bergeser $\mathrm{ke} \mathrm{CrO}_{4}{ }^{2-}$.

\section{Teori}

Lignin merupakan komponen makromolekul kayu ketiga. Gugus-gugus fungsi sangat mempengaruhi reaktivitas lignin, terdiri dari hidroksil fenolik, hidroksil benzilik dan gugus karbonil. Polimer lignin mengandung gugusgugus metoksil yang karakteristik, gugus hidroksil fenol, dan beberapa gugus aldehida ujung dalam rantai samping (Sjostrom, 1995). Jumlah gugus metoksil dalam lignin bergantung pada sumber lignin dan proses isolasi yang digunakan. Kandungan gugus metoksil pada kayu daun jarum sebesar $14-15 \%$ sedangkan pada kayu daun lebar sebesar $20-21 \%$ (Cahyani, 1999). Lignin dapat diperoleh dari proses pemasakan serbuk kayu menggunakan larutan $\mathrm{NaOH}$. Polimer lignin akan terdegradasi dan kemudian larut dalam larutan pemasak. Lignin merupakan komponen terbesar yang terdapat dalam larutan sisa pemasak, karena itu proses isolasi lignin lebih memungkinkan. Berbagai teknik isolasi telah dipelajari, tetapi pada prinsipnya sama yaitu diawali dengan proses pengendapan padatan. Menurut Sjostrom (1995), isolasi lignin dibedakan pada tiga metode yaitu isolasi dengan pengasaman yang menggunakan pereaksi anorganik seperti $\mathrm{H}_{2} \mathrm{SO}_{4}$ pekat atau $\mathrm{HCl}$ pekat, isolasi dengan metode Cellulolytic Enzyme Lignins (CEL), dan Milled Wood Lignin (MWL). Pengendapan lignin dari lindi hitam yang diperoleh dari hasil pemasakan terjadi sebagai akibat adanya reaksi kondensasi pada unit-unit penyusun lignin yang semula larut akan mengalami repolimerisasi dan membentuk molekul yang lebih besar. Sjostrom (1995) mengemukakan bahwa isolasi yang dilakukan pada $\mathrm{pH}$ rendah menghasilkan rendemen lignin yang tinggi.

\section{Mekanisme adsorpsi}

Salah satu metode yang digunakan untuk menghilangkan zat pencemar dari air limbah adalah adsorpsi (Rios et al. 1999 dan Saiful et al. 2005). Adsorpsi merupakan terjerapnya suatu zat (molekul atau ion) pada permukaan adsorben. Mekanisme penjerapan tersebut dapat dibedakan menjadi dua yaitu, jerapan secara fisika (fisisorpsi) dan jerapan secara kimia (kemisorpsi). Adsorpsi dari larutan adalah penyisihan suatu adsorbat dari larutan dengan penempelan pada permukaan substrat yang berada dalam suspense "aqueous", pada $\mathrm{pH}$ tertentu (Cahyani, 1999). Adsorpsi dalam larutan biasanya terjadi pada antar muka cair-gas, caircair atau cair-padat. Pada antar muka cair-padat terdapat sistem 3 komponen, yaitu yang diadsorpsi (solut atau terlarut), yang mengadsorpsi (adsorben, padat) dan pelarut (cairan), dimana interaksi yang terjadi tidak hanya antara solut-adsorben, solut-pelarut, pelarut-adsorben tetapi juga solut-solut (Tamamushi, 1983 dalam Cahyani 1999).

Struktur molekul polimer lignin terdiri atas sistem aromatik yang tersusun atas unit-unit fenil propana. Adsorpsi logam-logam oleh polimer terjadi melalui proses penyerapan yang melibatkan gugus-gugus fungsional yang terikat pada makromolekul seperti protein, polisakarida, lignin, khitin dan, khitosan. Gugus fungsional dimaksud meliputi gugus-gugus karboksilat, hidroksil, imidazol, sulfohidril, dan fosfat.

\section{Mekanisme kopresipitasi}

Beberapa peneliti menunjukkan bahwa proses kopresipitasi merupakan mekanisme penting pada penyisihan ion dalam larutan. Crawford (1996) menyatakan bahwa adsorpsi dan kopresipitasi memperbaiki tingkat pemisahan logam berat dari larutannya dibanding cara presipitasi biasa (Crawford, 1996). Menurut Crawford, proses kopresipitasi cenderung lebih efektif dalam pemisahan ion logam berat dari larutan air, dibanding proses adsorpsi. Pada proses kopresipitasi, adsorben ditambahkan dalam bentuk larutannya, selanjutnya adsorben padat terbentuk bersamaan dengan penyerapan bahan terlarut (solute) melalui proses oklusi selama pengaturan $\mathrm{pH}$ larutan, sehingga suatu campuran endapan terbentuk, karena selain adsorpsi akan terjadi juga kopresipitasi bahan terlarut bersamaan dengan pembentukan partikel adsorben. 


\section{BAHAN DAN METODE}

\section{Alat dan Bahan}

Peralatan yang digunakan adalah Spektrofotometer UV-Vis Shimadzu, pH-meter Orion, timbangan analitik Mettler AE.50, pengaduk magnet Heidolp MR 1000, FTIR-8000 PC Shimadzu, kertas saring Whatman 42, alat sentrifugasi, dan alat-alat gelas.

Bahan yang digunakan adalah lignin hasil isolasi dari lindi hitam, $\mathrm{NaOH}$ p.a dari Merck, $\mathrm{H}_{2} \mathrm{SO}_{4}$ 96-98 \% p.a dari Merck, Larutan $\mathrm{HNO}_{3}$ $65 \%$ p.a dari Merck, $\mathrm{H}_{3} \mathrm{PO}_{4} 85 \%$ p.a dari Merck, difenilkarbazid (DPC) $0,25 \%$, padatan $\mathrm{K}_{2} \mathrm{Cr}_{2} \mathrm{O}_{7}$ p.a dari Merck, akuades.

\section{Metoda}

\section{Preparasi lignin dan penentuan kondisi optimum}

Serbuk kayu dimasak dengan larutan pemasak $\mathrm{NaOH} 5 \%$. Hasil pemasakan diperoleh filtrat yang berwarna hitam (lindi hitam). Dari lindi hitam, diendapkan ligninnya dengan pengasaman menggunakan $\mathrm{H}_{2} \mathrm{SO}_{4} 10 \%$ sampai $\mathrm{pH}$ 2. Larutan ditiris secara perlahan dan disaring mengunakan Whatman 42. Lignin dicuci dengan akuades sampai $\mathrm{pH}$ netral, kemudian dikering dalam oven temperatur $90^{\circ} \mathrm{C}$ dan disimpan dalam desikator. Lignin yang diperoleh dianalisis menggunakan FTIR.

Penentuan panjang gelombang maksimum dilakukan dengan pengukuran absorbansi $15 \mathrm{~mL}$ larutan standar $\mathrm{Cr}(\mathrm{VI}) \quad 0,6 \mathrm{ppm}$ yang telah ditambah dengan $\mathrm{H}_{2} \mathrm{SO}_{4}$ sampai $\mathrm{pH} 1 \pm 0,3$. Ditambahkan 0,5 mL DPC. Kemudian didiamkan selama 5-10 menit dan diukur absorbansinya pada $\lambda 400 \mathrm{~nm}-800 \mathrm{~nm}$ dengan running menggunakan spektrofotometer UV-Vis.

Penentuan kestabilan kompleks $\mathrm{Cr}$ difenilkarbazon dilakukan dengan cara, sebanyak $10 \mathrm{~mL}$ larutan $\mathrm{Cr}(\mathrm{VI})$ 0,8 ppm yang telah ditambah $\mathrm{H}_{2} \mathrm{SO}_{4}$ sampai $\mathrm{pH} \quad 1 \pm 0,3$ ditambahkan 0,5 mL DPC. Larutan didiamkan, ukur absorbansi dengan spektrofotometer UVVis pada $\lambda$ maksimum dimulai pada menit ke-3 sampai menit ke-13 dengan rentang 1 menit.

Pembuatan kurva standar dilakukan dengan cara, sebanyak $25 \mathrm{~mL}$ larutan $\mathrm{Cr}(\mathrm{VI})$ masing-masing konsentrasi 0,3 ppm, 0,4 ppm, 0,5 ppm, 0,6 ppm, 0,7 ppm, 0,8 ppm, dan 1,0 ppm tambahkan $\mathrm{H}_{2} \mathrm{SO}_{4}$ sampai $\mathrm{pH}$ 1+0,3. Kemudian ditambahkan $0,5 \mathrm{~mL}$ DPC dan didiamkan selama \pm 9 menit. Ukur absorbansi masing-masing larutan dengan spektrofotometer UV-Vis pada $\lambda 542 \mathrm{~nm}$. Kurva standar $\mathrm{Cr}(\mathrm{VI})$ dibuat berdasarkan persamaan regresi linear $Y$ $=\mathrm{aX}$.

\section{Penyisihan $\mathrm{Cr}(\mathrm{VI})$ oleh lignin dengan 3} cara pengaturan $\mathrm{pH}$

1) Lignin $(\mathrm{pH} 13)+$ larutan $\mathrm{Cr}(\mathrm{VI})(\mathrm{pH} 2)$

Tambahkan larutan lignin 600 ppm ke dalam larutan $\mathrm{Cr}(\mathrm{VI})$ hingga dicapai berbagai variasi $\mathrm{pH}$ (2-10). Tiap-tiap $\mathrm{pH}$ campuran disentrifugasi, diambil $1 \mathrm{~mL}$ bagian atas dan diencerkan dalam labu takar $25 \mathrm{~mL}$. Amati banyaknya $\mathrm{Cr}(\mathrm{VI})$ yang tersisih menggunakan spektrofotometer UV-Vis dengan pereaksi DPC yang diukur pada $\lambda 542 \mathrm{~nm}$.

\section{2) Larutan $\mathrm{Cr}(\mathrm{VI})(\mathrm{pH} 2)+$ lignin $(\mathrm{pH} \mathrm{13})$}

Tambahkan larutan $\mathrm{Cr}(\mathrm{VI}) 25 \mathrm{ppm}$ ke dalam larutan lignin 600 ppm hingga dicapai berbagai variasi $\mathrm{pH}$ (2-10). Tiap-tiap $\mathrm{pH}$ campuran disentrifugasi, diambil $1 \mathrm{~mL}$ bagian atas dan diencerkan dalam labu takar $25 \mathrm{~mL}$. Amati banyaknya $\mathrm{Cr}(\mathrm{VI})$ yang tersisih menggunakan spektrofotometer UV dengan pereaksi DPC yang diukur pada $\lambda 542 \mathrm{~nm}$

3) Campur larutan $\mathrm{Cr}(\mathrm{VI})$ dan larutan lignin Campur $25 \mathrm{~mL}$ larutan $\mathrm{Cr}(\mathrm{VI}) 25 \mathrm{ppm}$ (pH 2) dan $25 \mathrm{~mL}$ larutan lignin 600 ppm (pH 13) dan atur $\mathrm{pH}$ campuran menjadi 2-10 menggunakan $\mathrm{H}_{3} \mathrm{PO}_{4}$. Pada masing-masing $\mathrm{pH}$, campuran disentrifugasi, dipipet $1 \mathrm{~mL}$, diencerkan menjadi $25 \mathrm{~mL}$. Amati penyisihan $\mathrm{Cr}(\mathrm{VI})$ menggunakan spektrofotometer UV-Vis dengan pereaksi $D P C$ yang diukur pada $\lambda 542$ $\mathrm{nm}$.

\section{Pengaruh konsentrasi lignin terhadap penyisihan $\mathrm{Cr}(\mathrm{VI})$}

Campur $10 \mathrm{~mL}$ larutan $\mathrm{Cr}(\mathrm{VI}) 25$ ppm $(\mathrm{pH} 2)$ dan $25 \mathrm{~mL}$ larutan lignin $\mathrm{pH} 13$ masingmasing konsentrasi 900 ppm, 1000 ppm, 1500 ppm, dan 2000 ppm. Atur pH campuran menjadi 2-8 dengan menambahkan $\mathrm{H}_{3} \mathrm{PO}_{4}$. Pada masing-masing $\mathrm{pH}$ dan konsentrasi lignin, campuran disentrifugasi, dipipet $1 \mathrm{~mL}$, diencerkan menjadi $10 \mathrm{~mL}$. Amati banyaknya $\mathrm{Cr}(\mathrm{VI})$ yang tersisih menggunakan spektrofotometer UV-Vis dengan pereaksi DPC yang $\lambda 542 \mathrm{~nm}$.

\section{Analisis data}

Untuk mendapatkan persen penyisihan $\mathrm{Cr}(\mathrm{VI})$ menggunakan rumus (1) dan persamaan kurva standar.

$\%$ Penyisihan $=\frac{\mathrm{Ms} \mathrm{Cr}(\mathrm{VI})_{1}-\mathrm{Ms} \mathrm{Cr}(\mathrm{VI})_{2}}{\mathrm{Ms} \mathrm{Cr}(\mathrm{VI})_{1}} \times 100 \%$

Keterangan:

Ms $\mathrm{Cr}(\mathrm{VI})_{1}=$ Massa $\mathrm{Cr}(\mathrm{VI})$ awal

Ms $\mathrm{Cr}(\mathrm{VI})_{2}=$ Massa $\mathrm{Cr}(\mathrm{VI})$ dalam supernatan 


\section{HASIL DAN PEMBAHASAN}

\section{Preparasi lignin dan persamaan kurva standar}

Hasil isolasi menunjukkan bahwa kadar lignin yang merupakan perbandingan antara berat lignin (gram) yang diperoleh dengan volume larutan $(\mathrm{mL})$ lindi hitam yang diisolasi yaitu sebesar $1,941 \% \quad(b / v)$. Analisis FTIR terhadap lignin hasil isolasi diperoleh spektrum seperti Gambar 1 berikut.

Pada Gambar 1 menunjukkan adanya serapan spesifik dari gugus fungsi lignin yaitu pada daerah $1326,93 \mathrm{~cm}^{-1}$ yang merupakan vibrasi cincin sringil sebagai prazat penyusun lignin dan diperkuat oleh munculnya serapan pada $1124,42 \mathrm{~cm}^{-1}$ sebagai deformasi $\mathrm{C}-\mathrm{H}$ aromatis tipe sringil. Menurut Hergert (1971) dalam Fengel (1995), serapan khas guaiasil dan siringil (vibrasi cincin) masing-masing terdapat pada bilangan gelombang sekitar $1270-1330 \mathrm{~cm}^{-}$

1 . Dominasi gugus $-\mathrm{OH}$ ditandai dengan puncak serapan yang sangat karakteristik pada daerah $3444,63 \mathrm{~cm}^{-1}$ sebagai vibrasi ulur $-\mathrm{OH}$. Sedangkan rentangan $\mathrm{C}=\mathrm{O}$ terkonjugasi dengan cincin aromatis muncul pada daerah 1676,03 $\mathrm{cm}^{-1}$. Sesuai dengan penelitian Sucipto (2009) bahwa komponen kimia lignin isolat dari lindi hitam memiliki ciri yang mirip dengan lignin standar indulin-AT.

Kurva standar yang diperoleh ditunjukkan pada Gambar 2 dengan persamaan $Y=0,7011 X$ dan $\mathrm{R}^{2}=0,9979$.

\section{Kemampuan Lignin terhadap penyisihan $\mathrm{Cr}(\mathrm{VI})$ menggunakan 3 cara pengaturan $\mathrm{pH}$}

Hasil penyisihan $\mathrm{Cr}(\mathrm{VI})$ yang diperoleh dari 3 metode pengaturan $\mathrm{pH}$ yang digunakan ditunjukkan pada Gambar 3 berikut.

Berdasarkan Gambar 3, metode pengaturan $\mathrm{pH}$ dengan mencampur antara larutan lignin dan larutan $\mathrm{Cr}(\mathrm{VI})$ memberikan penyisihan $\mathrm{Cr}(\mathrm{VI})$ sebesar $57,12 \%$ pada $\mathrm{pH} 2$.

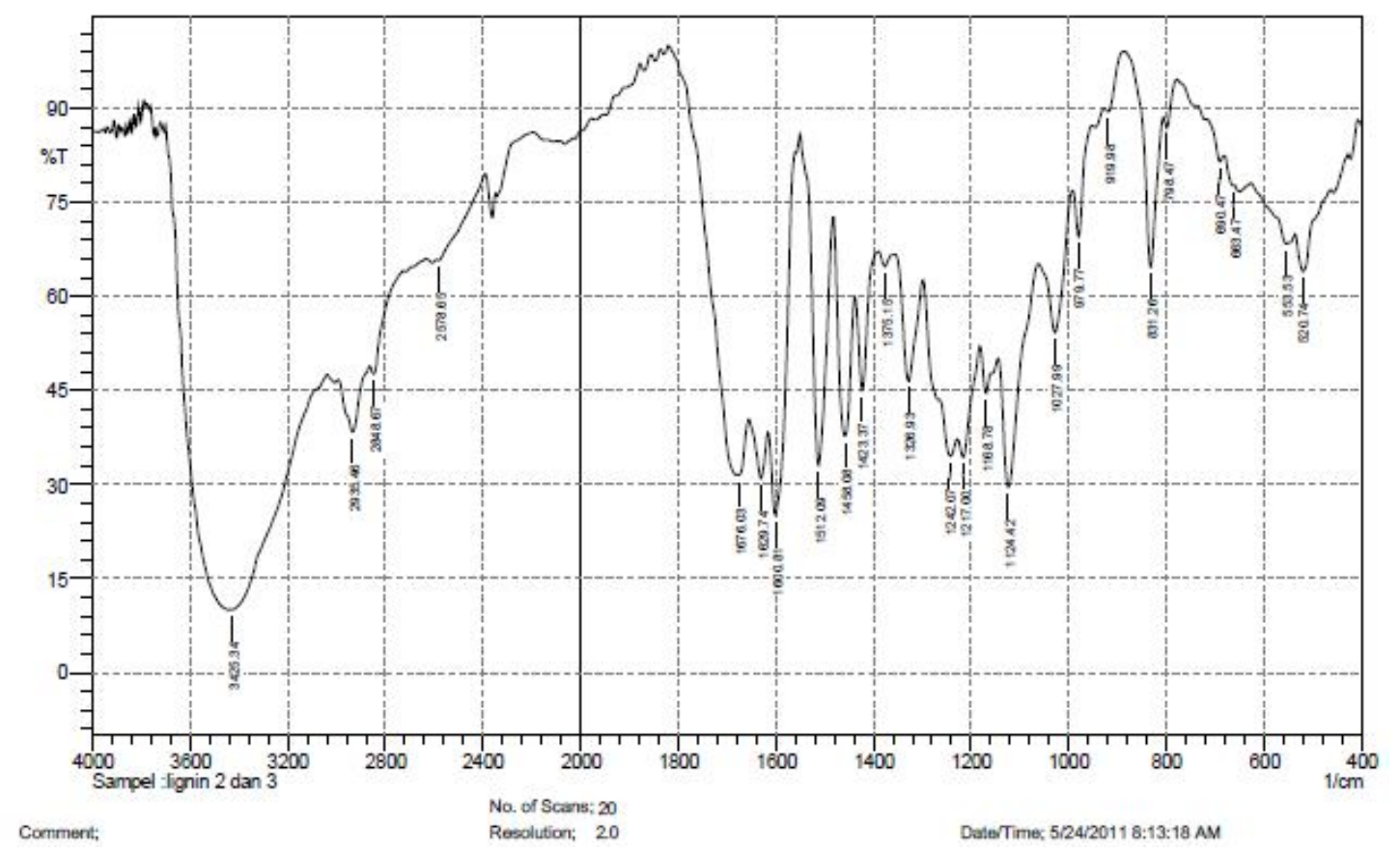

Gambar 1. Spektrum infra merah lignin hasil isolasi 


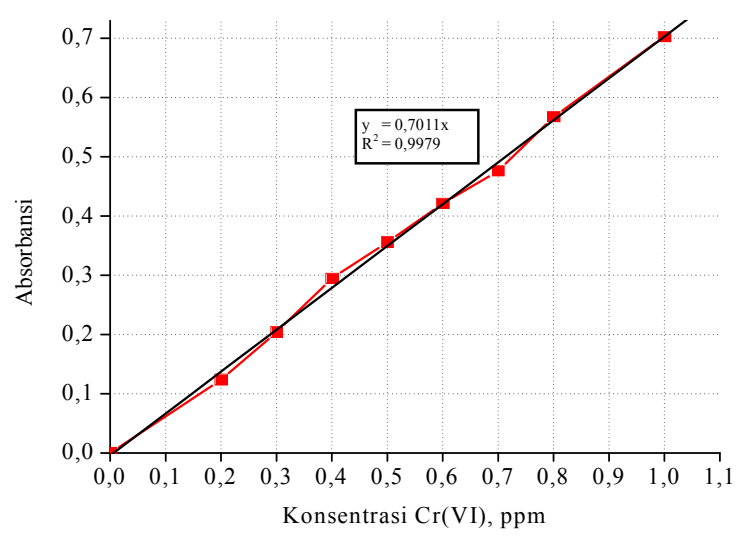

Gambar 2. Kurva Standar Cr(VI)

\section{Pengaruh $\mathrm{pH}$ terhadap penyisihan $\mathrm{Cr}(\mathrm{VI})$ oleh lignin}

Penggunaan larutan lignin 500 ppm menunjukkan terjadi penyisihan $\mathrm{Cr}(\mathrm{VI})$ pada $\mathrm{pH}$ 2 sebesar 56,45\%. Hal ini ditunjukkan pada Gambar 4 menunjukkan bahwa, penyisihan $\mathrm{Cr}(\mathrm{VI})$ oleh lignin semakin kecil seiring dengan bertambahnya $\mathrm{pH}$ campuran, sesuai dengan penelitian Albadarin A.B (2011). Hal ini disebabkan karena dengan bertambahnya $\mathrm{pH}$ jumlah gugus $-\mathrm{OH}$ yang terprotonasi berkurang sehingga interaksi elektrostatik $-\mathrm{OH}$ terprotonasi dengan spesi $\mathrm{Cr}(\mathrm{VI})$ berkurang. Disamping itu, semakin besar $\mathrm{pH}$ jumlah $\mathrm{CrO}_{4}^{2-}$ semakin banyak dibanding $\mathrm{HCrO}_{4}^{-}$sehingga gaya tolakan menjadi lebih besar.

Semakin besarnya $\mathrm{pH}$ juga menaikkan jumlah ion $\mathrm{OH}^{-}$, adanya ion $\mathrm{OH}^{-}$akan berkompetisi dengan anion $\mathrm{Cr}(\mathrm{VI})$ untuk berinteraksi dengan lignin dan menyebabkan proses deprotonasi yang menyebabkan lignin bermuatan negatif. Cahyani (1999)

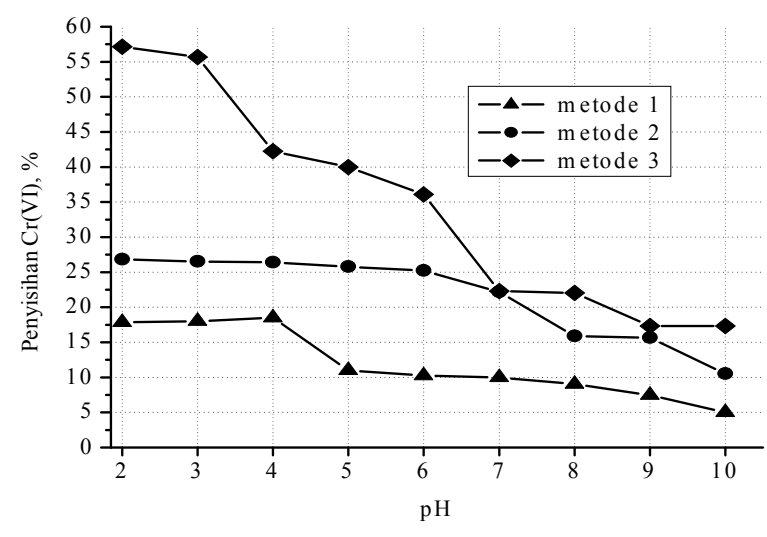

Gambar 3. Penyisihan Cr(VI menggunakan 3 cara pengaturan $\mathrm{pH}$

menyebutkan, pada $\mathrm{pH} 5$ atau lebih tinggi partikel lignin bermuatan negatif.

Mekanisme penyisihan yang mungkin terjadi adalah adsorpsi dan kopresipitasi. Peristiwa adsorpsi diduga terjadi karena gugus fungsi lignin yaitu hidroksil mengalami protonasi sehingga bermuatan positif. Hal ini sesuai dengan hasil penelitian Cahyani (1999) bahwa i.e.p (isoelectric point) dari lignin adalah 2,3, yang berarti bahwa pada $\mathrm{pH}$ di bawah i.e.p lignin bermuatan positif. Reaksi protonasi yang terjadi seperti Gambar 5 sebagai berikut.

$\mathrm{Cr}(\mathrm{VI})$ pada larutan asam antara $\mathrm{pH} 2$ sampai dengan $\mathrm{pH} 6$ terbentuk spesi $\mathrm{HCrO}_{4}{ }^{-}$dan $\mathrm{Cr}_{2} \mathrm{O}_{7}{ }^{2-}$ sehingga memungkinkan terjadi interaksi gugus $\mathrm{OH}$ terprotonasi dengan anion $\mathrm{Cr}(\mathrm{VI})$ melalui interaksi elektrostatik dan pembentukan ikatan silang (cross linking). Diduga mekanisme interaksi elektrostatik yang terjadi dapat dilihat pada Gambar. 6. Memungkinkan juga terjadi ikatan silang melalui mekanisme reaksi yang dapat dilihat pada Gambar 7.

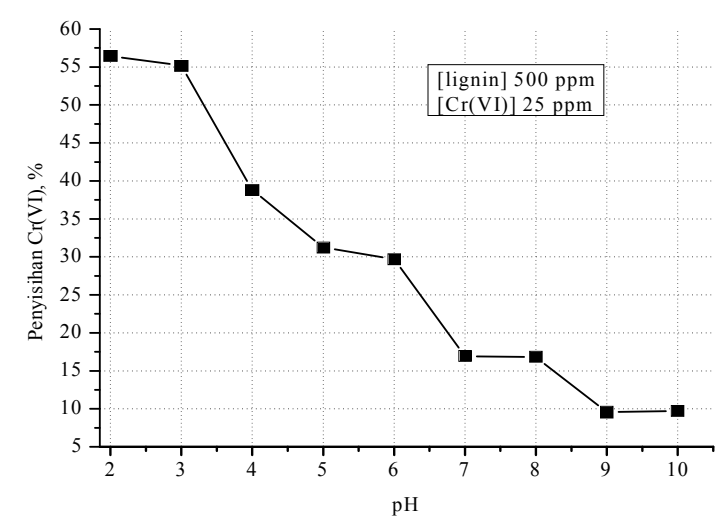

Gambar 4. Pengaruh $\mathrm{pH}$ terhadap penyisihan $\mathrm{Cr}(\mathrm{VI})$ 


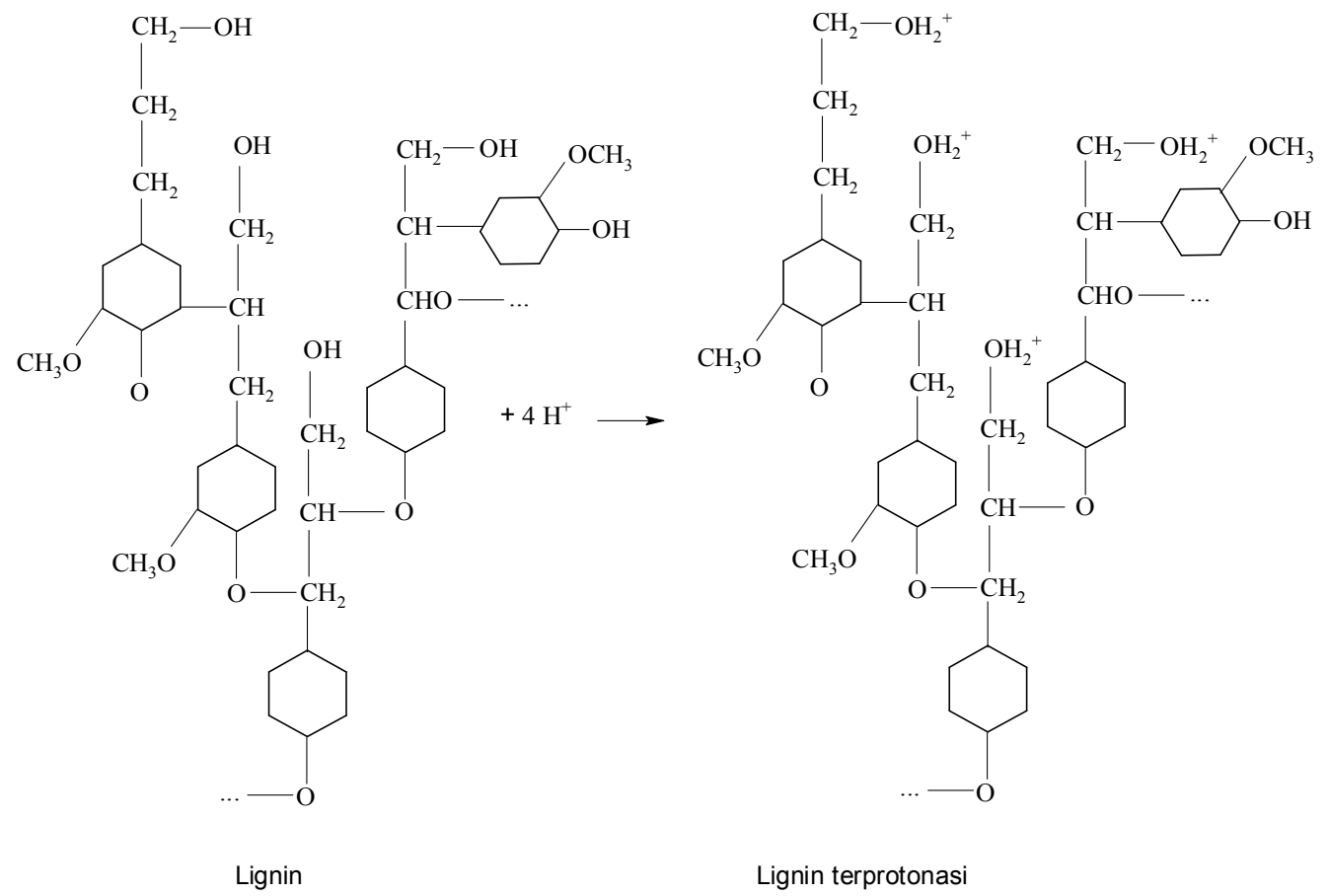

Gambar 5. Reaksi protonasi lignin

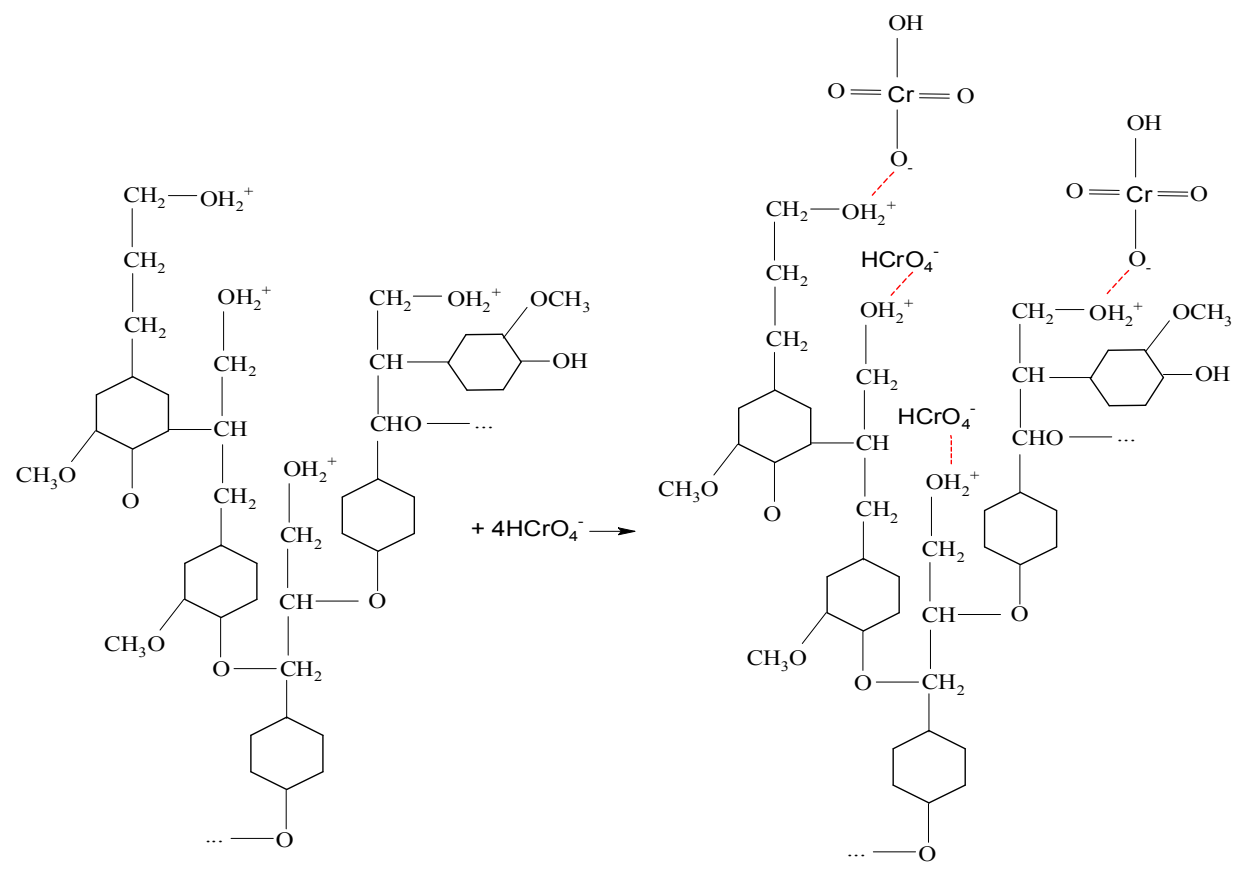

Gambar 6. Mekanisme interaksi elektrostatik 


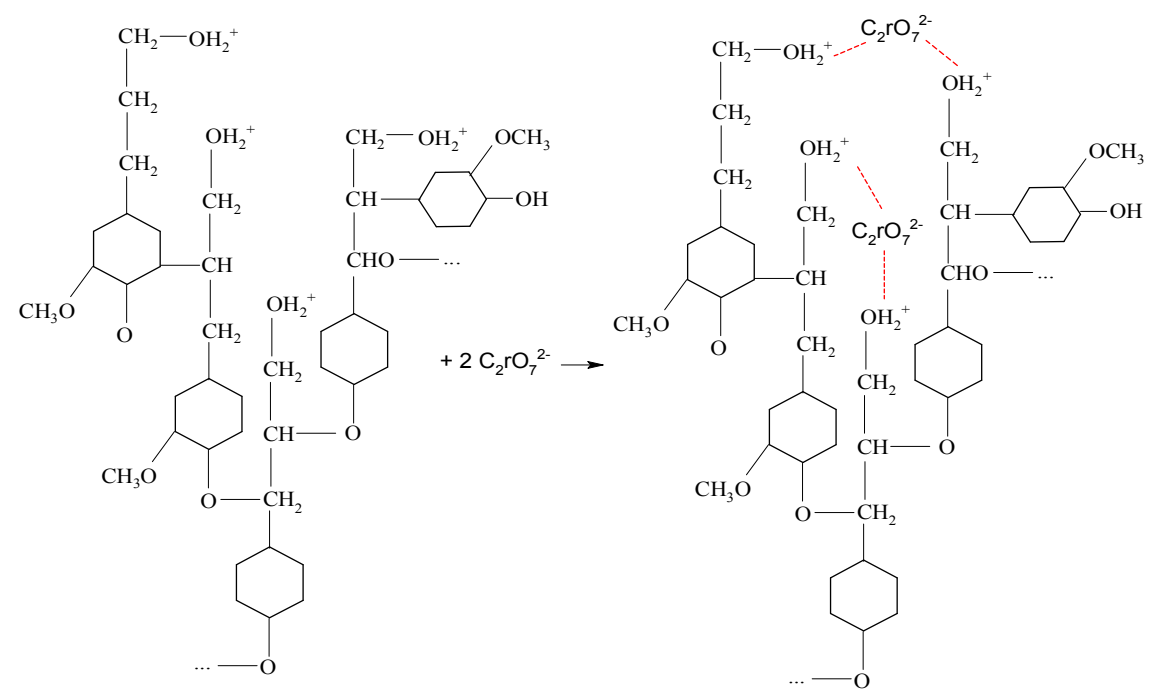

Gambar 7. Mekanisme pembentukan ikatan silang (cross linking)

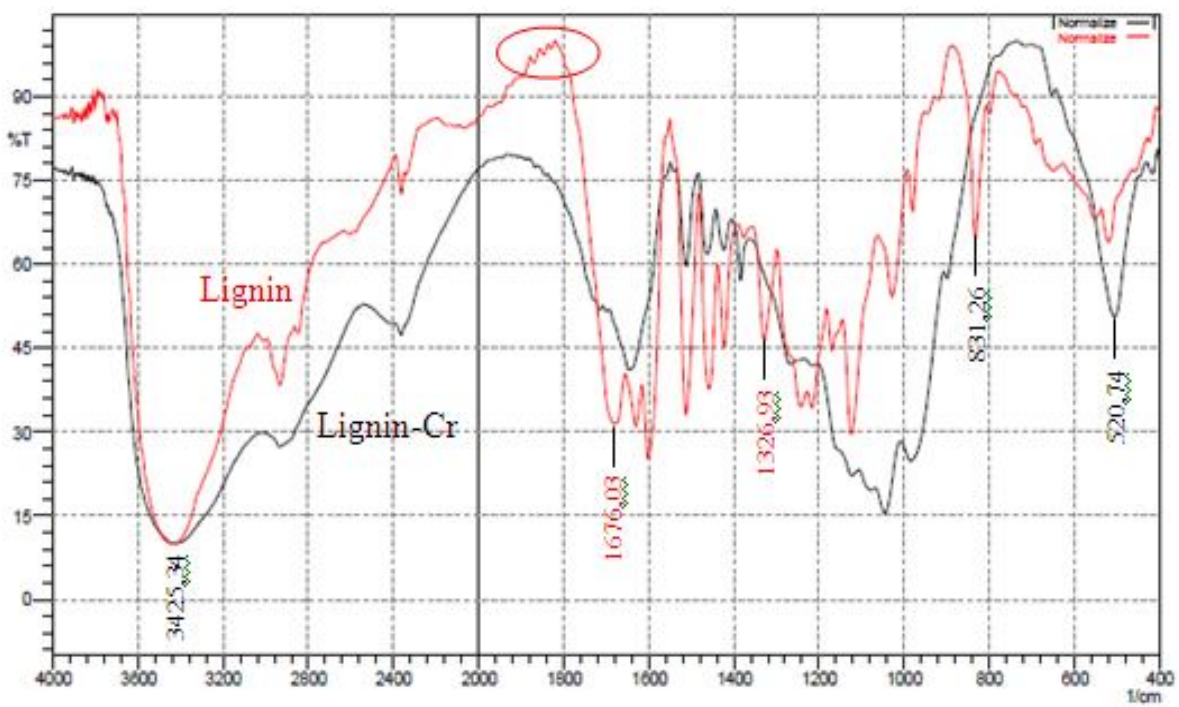

Gambar 8. Spektrum infra merah lignin setelah berinteraksi dengan $\mathrm{Cr}(\mathrm{VI})$

Proses kopresipitasi melalui mekanisme oklusi, yaitu molekul kecil terjebak di dalam ruang intra partikel terjadi karena lignin yang merupakan polimer 3 dimensi yang pada $\mathrm{pH}$ rendah mengalami repolimerisasi membentuk struktur yang melingkar melalui ikatan antara unit-unit lignin sehingga terbentuk pori atau ruang intra partikel yang menyebabkan ion $\mathrm{HCrO}_{4}^{-}$teroklusi (terjebak) dalam ruang tersebut dan mengalami kopresipitasi seiring dengan mulai mengendapnya lignin
Peristiwa adsorpsi dan kopresipitasi melalui interaksi elektrostatik, crosslinking serta oklusi dibuktikan oleh hasil FTIR dari endapan lignin setelah berinteraksi dengan $\mathrm{Cr}(\mathrm{VI})$ sesuai dengan Gambar 8.

Berdasarkan Gambar 8, terlihat bahwa terjadi interaksi lignin dan spesi $\mathrm{Cr}(\mathrm{VI})$ dengan adanya serapan yang hilang pada daerah 1676 $\mathrm{cm}^{-1}, \quad 1326,93 \mathrm{~cm}^{-1}$, dan 831,26 $\mathrm{cm}^{-1}$. Ditunjukkan juga muncul serapan kuat di daer ah $520,74 \mathrm{~cm}^{-1}$ sebesar $51 \% \mathrm{~T}$ yaitu vibrasi kisi Cr-O (James E.A and Dhanpat R., 1990). 
Adanya mekanisme protonasi dan crosslinking ditunjukkan oleh hilangnya spektrum jari pada pita serapan $1800-2000 \mathrm{~cm}^{-1}$ yang menunjukkan senyawa fenolik dan pelebaran serapan pada daerah $3425,24 \mathrm{~cm}^{-1}$ diduga karena peristiwa crosslinking yang menyebabkan vibrasi $-\mathrm{OH}$ terstabilkan.

\section{Pengaruh konsentrasi lignin terhadap penyisihan $\mathrm{Cr}(\mathrm{VI})$}

Variasi konsentrasi terhadap penyisihan $\mathrm{Cr}(\mathrm{VI})$ pada $\mathrm{pH}$ 2-8, diperoleh Gambar 9.

Berdasarkan Gambar 9, terdapat peningkatan jumlah $\mathrm{Cr}(\mathrm{VI})$ yang tersisihkan dengan bertambahnya konsentrasi lignin. Teramati, pada $\mathrm{pH}<5$ terdapat kecenderungan persen penyisihan naik seiring dengan naiknya konsentrasi lignin hal ini diduga karena dengan bertambahnya lignin maka tersedia permukaan lignin terprotonasi yang lebih luas untuk berinteraksi dengan anion $\mathrm{Cr}(\mathrm{VI})$. Kemungkinan lain adalah, semakin tinggi konsentrasi lignin maka akan meningkatkan jumlah ruang intra partikel sehingga meningkatkan proses oklusi dan terkopresipitasi. Terlihat pada $\mathrm{pH}$ larutan 2, terjadi kenaikan persen penyisihan sebesar $59,92 \%$ pada konsentrasi 800 ppm (1:80) menjadi $85,83 \%$ ketika konsentrasi lignin 2000 ppm (1:200).

Sedangkan Pada $\mathrm{pH}>5$, kenaikan konsentrasi lignin tidak terlalu berpengaruh terhadap penyisihan $\mathrm{Cr}(\mathrm{VI})$, terlihat pada $\mathrm{pH} 6$ dengan konsentrasi lignin $900 \mathrm{ppm}$ mampu menyisihkan $\mathrm{Cr}(\mathrm{VI})$ sebesar $42,83 \%$ naik sebesar 2,96\% menjadi $45,79 \%$ ketika konsentrasi lignin $2000 \mathrm{ppm}$. Hal yang sama juga teramati pada $\mathrm{pH} 8$, yaitu menyisihkan $\mathrm{Cr}(\mathrm{VI})$ sebanyak $24,00 \%$ pada konsentrasi lignin 1000 ppm menjadi $24,97 \%$ ketika konsentrasi lignin 2000 ppm (naik 0,97\%).

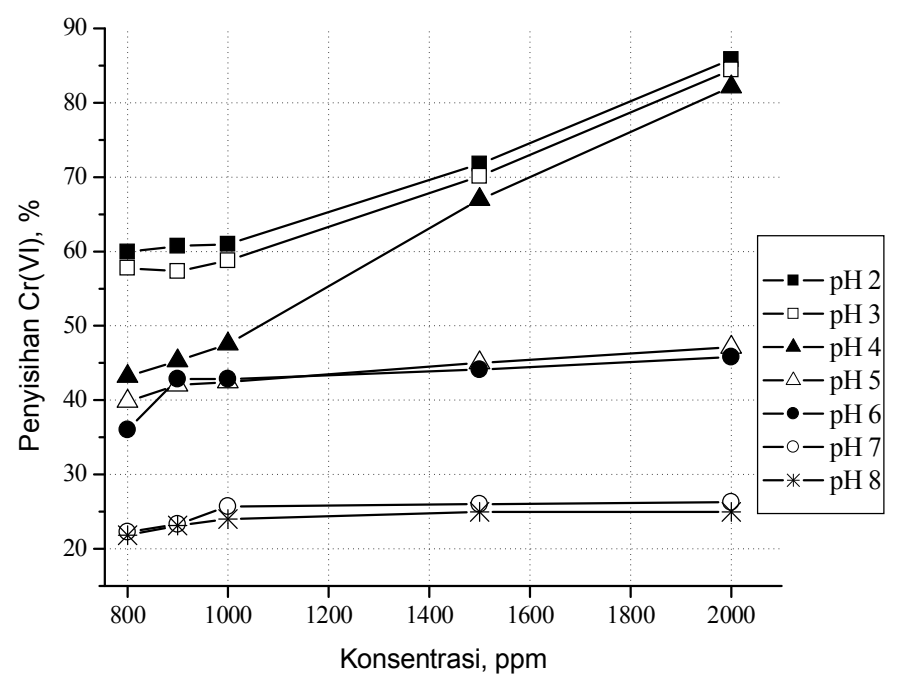

Gambar 9. Variasi konsentrasi lignin terhadap penyisihan $\mathrm{Cr}(\mathrm{VI})$

\section{KESIMPULAN}

Dari hasil percobaan diperoleh beberapa kesimpulan sebagai berikut:

1. Cara pengaturan $\mathrm{pH}$ terbaik adalah mencampur terlebih dahulu antara larutan lignin dengan larutan $\mathrm{Cr}(\mathrm{VI})$ kemudian diatur $\mathrm{pH}$ campuran. Cara ini mampu menyisihkan $\mathrm{Cr}(\mathrm{VI})$ sebesar $85,83 \%$ dari konsentrasi $\mathrm{Cr}(\mathrm{VI}) 25 \mathrm{ppm}$ sebanyak $10 \mathrm{~mL}$ menjadi $1,012 \mathrm{ppm}$ dengan penggunaan lignin sebesar 2000 ppm sebanyak $25 \mathrm{~mL}$ pada pH campuran 2.

2. Kemampuan lignin terhadap penyisihan $\mathrm{Cr}(\mathrm{VI})$ semakin berkurang dengan bertambahnya $\mathrm{pH}$. Sedangkan penambahan konsentrasi lignin pada $\mathrm{pH}<5$ dapat menaikkan penyisihan $\mathrm{Cr}(\mathrm{VI})$ karena terjadi proses adsorbsi dan kopresipitasi melalui mekanisme oklusi sedangkan pada $\mathrm{pH}>5$ peristiwa kopresipitasi tidak terjadi. 


\section{DAFTAR PUSTAKA}

Achmadi, S.S. 1990. Kimia Kayu. Bogor: Departemen Pendidikan dan Kebudayaan, Direktorat Pendidikan Tinggi, Pusat Antar Universitas Bioteknologi, Institut Pertanian Bogor.

Albadarina, A.B., A.H. AlMuhtaseb, N.A. Aliaqtah. 2011. Biosorption of toxic chromium from aqueous phase by lignin: mechanism, effect of other metal ions and salts, Chemical Engineering Journal $169: 20-30$

American Public Health Association (APHA). 1976. Standard methods for the examination of water and wastewater, 4th edition, APHA, Washington DC, p1193

Aroua. M.K., F.M.Zuki, N.M and Sulaiman. Removal of chromium ions from aqueous solutions by polymerenhanced ultrafiltration. Kuala Lumpur, Malaysia :Department of Chemical Engineering, Faculty of Engineering, University of Malaya.

Cahyani, C. 1999. Adsorpsi, Kopresipitasi dan Flotasi untuk Penyisihan Lignin dari Larutannya. Disertasi. Institut Teknologi Bandung, Bandung. Indonesia.

Casey,J.P. 1980. Pulp and Paper Chemistry and Chemical Technology. 3rd edition Vol. I A. New York: Willey Interscience Publisher.

Celik, A., and Dermibas, A. 2005. Removal of heavy metal ions from aqueous solution via adsorption onto modified lignin from pulping wastes, Energy Sources Part A: Recovery, Utilization and Environmental. 27: 1167-1177.

Chang, L.Y. 2001. "Chrome Reduction and Heavy Metals Removal From Wastewater - A Pollution Prevention Approach", WM'01 Conference, Tucson.

Crawford, R.J. 1995. Adsorption and Coprecipitation of Heavy Metals.PhD Thesis. Departement of Physical Chemistry, The University of Melbourne. Australia.

Dence, C.W and S.Y.Lin. 1992. Method in Lignin Chemistry. Spinger-Verlag. Berlin: Spinger series in wood series pp 33-61

Ekman, K.H., and J.J Lindberg. 1960. On the origin of the infra-red bands in the $1720 \mathrm{~cm}-1$ region in lignins, Pap. Рuи ,42. 21-22
Fengel, D., dan G. Wegener. 1995. Kayu; Kimia, Ultrastruktur dan Reaksi-reaksi. Yogjakarta: Gajah Mada University Press.

Gilligan, J. J. 1974. The Organic Chemicals Industries. Dalam Pyle, J. L., Chemistry and Technology Backlash. New York : Prentice-Hall, Inc.

Hemingway, R.W and H.C. Anthony. 1988. Adhesives from Renewable Resources, ACS Symposium, New Orleans, Washington DC.

Judoamidjojo, R.M., E.E. Said and Hartono. 1989. Biokonversi. Bogor : Departemen Pendidikan dan Kebudayaan. Direktorat Pendidikan Tinggi. Pusat Antar Universitas Bioteknologi, Institut Pertanian Bogor.

Karl Freudengerg, 1971. Lignins: Occurrence, Formation, Structure and Reactions, Wiley-Interscience. New York: John Wiley \& Sons, Inc.

Kim H, M.K hill and A.L. Fricke. 1987. Preparation of Kraft Lignin from Black Liqour. Tappi Journal 12: 112-115.

Kozlowski, C.A., and W. Walkowiak. 2002. Removal of chromium(VI) from aqueous solutions by polymers inclusion membranes, Water Res. 36 4870-4876.

Malik, J., A. Santoso dan Rahman. 2007. Sari Hasil Penelitian Mangium (Acacia mangium Willd). Dinas Kehutanan dan Perkebunan Kab. Tasikmalaya. http://www.dephut.go.id: diakses tanggal 12 Desember 2012.

Moore P., S. Kettle. and R. Wilkins. 1966. The kinetics of formation of blue peroxychromic acid in aqueous solution. Inorg. Chem. 5 : 466-467.

Saha, B., and C. Orvic. 2010. Biosorbents for Hexavalent Chromium Elimination from Industrial and Municipal effluenst, Coord. Chem. Rev. 254: 2959-2972

Saltzman, E.B. 2003. Microdetermination of Chromium with Diphenylcarbazide by Permanganate Oxidation, Improved Method of Oxidation and Color Development. Ohio : Devision of Occupational Health, Public Health Service, Federal Security Agency, Cincinnati 2.

Sarkanen, K.V., and C.H. Luding. 1971. Lignin: Occurrence, Formation, Structure and Reaction. New York : Wiley Interscience. 
Sjostrom, Eero. 1995. Kimia Kayu, Dasar-dasar dan Penggunaan. Edisi kedua. Yogyakarta: Gadjah Mada University Press

Stevenson, F. J. 1994. Humus Chemistry, Genesis, Composition, Reactions. 2nd Ed. New York : John Wiley \& Sons. Inc.

Vinodhini, V., and N. Das. 2009. Mechanism of $\mathrm{Cr}(\mathrm{VI})$ Biosorption by Neem Sawdust, American-Eurasian. Journal Scientific Research 4 (4): 324-329.

Vogel. 1985. Buku Teks Analisis Anorganik Kualitatif Makro Dan Semimikro. Edisi ke lima. Jakarta : PT. Kalaman Media Pusaka.

Wu, Y., Zhang , X. Guo, and H. Huang. 2008. Adsorption of chromium(III) on lignin.
Journal of Hazardous Materials 151: 134-142

Xia, L., E. Akiyama, G. Frankel and R. McCreerya. 2000. Storage and Release of Soluble Hexavalent Chromium from Chromate Conversion Coatings Equilibrium Aspects of CrVI Concentration. Journal of The Electrochemical Society 147 (7): 25562562.

Zink, S., R. Schoenberg and M.Staubwasser. 2010. Isotopic fractionation and reaction kinetics between $\mathrm{Cr}(\mathrm{III})$ and $\mathrm{Cr}(\mathrm{VI})$ in aqueous media. Journal Geochimica et Cosmochimica Acta. 74 : 5729-5745. 